\title{
Renewable energy technologies: enlargement of biofuels list and co-products from microalgae
}

\author{
Nadezhda I. Chernova ${ }^{1}$, Sofya V. Kiseleva ${ }^{1,2}$, Mikhail S. Vlaskin ${ }^{2}$, and Yulia Yu. Rafikova ${ }^{1, *}$ \\ ${ }^{1}$ Lomonosov Moscow State University, Moscow, Russia \\ ${ }^{2}$ Joint Institute for High Temperatures of Russian Academy of Science, Moscow, Russia
}

\begin{abstract}
Microalgae is a perspective feedstock for producing a wide variety of biofuels and co-products with high added value. An alternative to the traditional technology of biodiesel from algae by the transesterification is the technology of hydrothermal liquefaction (HTL). The article presents the results of promising strains screening and directed cultivation of microalgae for the processing by means of variety of technologies and production of valuable co-products. An algorithm for selecting suitable areas for industrial plantations of algae is presented.
\end{abstract}

\section{Introduction}

Among renewable energy sources biomass is one of the most popular: there is a significant increase in the scope and types of biomass use, recycling technology development and its application in the energy sector. Therefore, an urgent task is to find and study the use of new types of biomass, as well as the integrated technologies of its processing. In recent years the microalgae biotechnology which gives the opportunity to receive biofuels from microalgae are considered as a promising trend of bioenergy. Microalgae are very efficient solar energy converter that organizes the transformation of carbon dioxide into the complex energy consuming biomolecules comprising carbohydrates, proteins, lipids, which can be subjected to further transformation.

At the heart of research and engineering developments aimed on microalgal biofuel production lies the microalgae culture, which should grow rapidly, synthesize and accumulate a significant amount of lipids in the form of triacylglycerols and liquid carbohydrates $[1,2]$. Currently the whole number of microorganisms collections, particularly of microscopic algae, were created; in Russia collections of microalgae for energy purposes still are not created. The search of the perspective microalgae strains for energy purposes and creation of collections and efficient cultivation systems are certainly actual.

Development and testing of microalgae large-scale cultivation methods (MACs), as well as the methods of biomass processing into the suitable products, including energy products, was the topic of the authors study over the last years. The objects of the study were representatives of green and blue-green MACs: Chlorella, Dunaliella, Spirulina, Haematococcus, etc. [3, 4]. Due to uniqueness of the Spirulina/Arthrospira (A. platensis

*Corresponding author: ju.rafikova@gmail.com 
(Nordst.) Geitl.) biochemical composition, it was also studied as a biologically active food and feed additives. The tests of spirulina as a feed additive in poultry farming, cattle breeding and fur farming were carried out, guidelines for its application were developed and the patents of the Russian Federation were obtained.

Obviously, the most important factor in determining the profitability of the fuel production from biomass in general, and from microalgae - in particular, is the situation at the world oil market. A possible way to reduce the cost of biofuel from algae and to make it competitive on the market consists of using them to simultaneously obtain biofuels and high-value products, like nutraceuticals (BAA), phycocyanin, phycoerythrin and allophycocyanin, astaxanthin, chlorophyll, vitamin B12, polyunsaturated fatty acids omega3 and omega- 6 , and others. In case of using algae for sewage cleaning it is advisable to convert the biomass of MACs to methane or biofuel.

\section{Methodology and data analysis}

The introduction of advanced lipid strains into the biofuels production is complicated by following well-known fact: the simultaneous achievement of high productivity in biomass and lipids is impossible under the microalgae cultivation. Induction of lipid biosynthesis can be achieved by creating a physiological stress: limitation or starvation for nitrogen and/or phosphorus; maximum or minimum value of the light intensity, $\mathrm{pH}$, temperature; ultraviolet irradiation; effects of heavy metals and other chemicals, osmotic stress, and others. One of the possible way of maximizing the microalgae biomass accumulation with optimal lipid-content is the conducting cultivation in two stages. The first stage includes a maximum accumulation of biomass under standard growth conditions. At the second stage the production of biomass in stressful conditions to induce lipid synthesis is carried out.

As one of the most famous and expensive outdoor farmed species of microalgae/cyanobacteria remains A. platensis; it was used in the experiments under the two-step-cultivation and production of high lipid content in the algae. The object of the study were two clonal cultures of $A$. platensis: strain rsemsu 1/02-P (direct) and strain rsemsu 1/02-T (relaxed) as well as the culture of $H$. pluvialis rsemsu $H p-1 / 11$ resulting from the natural variability of morphological features. Testing of screening methods and selection of lipid-stress-conditions for lipid induction in microalgae have been conducted on spirulina [5]. As a result, samples of biomass with a high content of lipids were obtained (Table 1).

Traditionally, processing of algae biomass into biodiesel comprises drying, extraction of lipids, transesterification to give methyl esters of fatty acids constituting the biodiesel. At the same time the energy costs for drying and extraction is high. An alternative to this method is the HTL technology [6]. The main advantages of this method include the absence of pre-drying the feedstock and a relatively high yield (the ratio of product mass to the mass of raw material) due to the fact that all components of microalgae (lipids, proteins and carbohydrates) are converted into biofuel. In this case the main aim is to produce high biomass productivity of strains, rather than high lipid-content. However, the bio-oil produced from algae by HTL, is characterised by large amounts of nitrogen. This is due to high content of proteins in the original biomass. Therefore, the use of highly productive MAC strains with low-protein and, accordingly, high-lipid and/or carbohydrate still is important. 
Table 1. The biochemical composition of investigated strains microalgae at different growing conditions and the possible appropriate processing technology, \%

\begin{tabular}{|c|c|c|c|c|c|c|}
\hline $\begin{array}{l}\text { Genus/species/ } \\
\text { strain }\end{array}$ & $\begin{array}{l}\text { Cultivation } \\
\text { conditions }\end{array}$ & Proteins & $\begin{array}{l}\text { Neutral } \\
\text { lipids }\end{array}$ & $\begin{array}{c}\text { Total } \\
\text { carbohy } \\
\text { drates }\end{array}$ & $\begin{array}{l}\text { The optimal } \\
\text { processing } \\
\text { technology }\end{array}$ & The products \\
\hline \multirow{5}{*}{$\begin{array}{l}\text { A. platensis } \\
\text { rsemsu } 1 / 02-P\end{array}$} & \multirow[t]{2}{*}{$\begin{array}{l}\text { standard } \\
\text { conditions }\end{array}$} & \multirow[t]{2}{*}{60.7} & \multirow[t]{2}{*}{12.1} & \multirow[t]{2}{*}{7.1} & $\begin{array}{l}\text { 1) extraction } \\
\text { co-products }\end{array}$ & $\begin{array}{c}\text { phycocyanin, } \\
\beta \text {-carotene, } \\
\text { chlorophyll, } \\
\text { B12, } \\
\text { nutraceuticals } \\
\text { (BAA) }\end{array}$ \\
\hline & & & & & 2) HTL & bio-oil \\
\hline & $\begin{array}{c}\text { stress } \\
\text { conditions } \\
1^{1} \\
\end{array}$ & 39.2 & 26.1 & 34.7 & \multirow{3}{*}{$\begin{array}{l}\text { transesterifica } \\
\text { tion / acetone- } \\
\text { butanol- } \\
\text { ethanol } \\
\text { fermentation/ } \\
\text { HTL }\end{array}$} & \multirow{3}{*}{$\begin{array}{c}\text { biodiesel / } \\
\text { biohydrogen, } \\
\text { biobutanol, } \\
\text { ethanol/bio-oil }\end{array}$} \\
\hline & $\begin{array}{c}\text { stress } \\
\text { conditions } \\
2^{2}\end{array}$ & 24.3 & 30.9 & 24.3 & & \\
\hline & $\begin{array}{c}\text { stress } \\
\text { conditions } \\
3^{3} \\
\end{array}$ & 38.7 & 32.0 & 29.3 & & \\
\hline \multirow{4}{*}{$\begin{array}{l}\text { A. platensis } \\
\text { rsemsu } 1 / 02-T\end{array}$} & \multirow[t]{2}{*}{$\begin{array}{l}\text { standard } \\
\text { conditions }\end{array}$} & \multirow[t]{2}{*}{65.6} & \multirow[t]{2}{*}{13.5} & \multirow[t]{2}{*}{5.3} & $\begin{array}{l}\text { 1) extraction } \\
\text { co-products }\end{array}$ & $\begin{array}{l}\text { phycocyanin, } \\
\beta \text {-carotene, } \\
\text { chlorophyll, } \\
\text { B12, } \\
\text { nutraceuticals } \\
\text { (BAA) }\end{array}$ \\
\hline & & & & & 2) HTL & bio-oil \\
\hline & $\begin{array}{c}\text { stress } \\
\text { conditions } \\
4^{4}\end{array}$ & 30.5 & 36.1 & 33.4 & \multirow{2}{*}{$\begin{array}{l}\text { transesterifica } \\
\text { tion / acetone- } \\
\text { butanol- } \\
\text { ethanol } \\
\text { fermentation / } \\
\text { HTL }\end{array}$} & \multirow{2}{*}{$\begin{array}{l}\text { biodiesel/ } \\
\text { biohydrogen, } \\
\text { biobutanol, } \\
\text { ethanol/bio-oil }\end{array}$} \\
\hline & $\begin{array}{c}\text { stress } \\
\text { conditions } \\
5^{5} \\
\end{array}$ & 32.6 & 47.1 & 20.3 & & \\
\hline \multirow{3}{*}{$\begin{array}{c}\text { Haematococcus } \\
\text { pluvialis } \\
\text { rsemsu Hp-1/11 }\end{array}$} & $\begin{array}{l}\text { standard } \\
\text { conditions }\end{array}$ & 27.2 & 4.0 & 60.8 & $\begin{array}{l}\text { HTL/ acetone- } \\
\text { butanol- } \\
\text { ethanol } \\
\text { fermentation }\end{array}$ & $\begin{array}{c}\text { bio-oil/ } \\
\text { biodiesel/ } \\
\text { biohydrogen, } \\
\text { biobutanol, } \\
\text { ethanol }\end{array}$ \\
\hline & $\begin{array}{c}\text { stress } \\
\text { conditions } \\
6^{6}\end{array}$ & 13.3 & 16.8 & 60.9 & $\begin{array}{l}\text { 1) extraction } \\
\text { co-products }\end{array}$ & astaxanthin \\
\hline & & & & & $\begin{array}{c}\text { 2) } \\
\text { transesterifica } \\
\text { tion/acetone- } \\
\text { butanol- } \\
\text { ethanol } \\
\text { fermentation/ } \\
\text { HTL }\end{array}$ & $\begin{array}{l}\text { biodiesel/ } \\
\text { biohydrogen, } \\
\text { biobutanol, } \\
\text { ethanol/bio-oil }\end{array}$ \\
\hline
\end{tabular}

${ }^{1}$ stress conditions 1- Zarrouk's medium [7] that does not contain nitrogen and phosphorus; cultivation in open ponds of the volume $\mathrm{V}=20.01$ including the air barbotage (containing $2 \% \mathrm{CO}_{2}$ ); steadylighting conditions $\mathrm{I}=(160 \pm 5), \mu \mathrm{E} /\left(\mathrm{m}^{2} \mathrm{~s}\right) ; \mathrm{T}=25 \pm 1^{\circ} \mathrm{C}$; growing and photosynthesis (duration) 15 days. 


\begin{abstract}
${ }^{2}$ stress conditions 2 - Zarrouk's medium that does not contain nitrogen and phosphorus; cultivation in open ponds of the volume $\mathrm{V}=20.01$ including the air barbotage (containing $2 \% \mathrm{CO}_{2}$ ); steady-lighting conditions $\mathrm{I}=(250 \pm 5), \mu \mathrm{E} /\left(\mathrm{m}^{2} \mathrm{~s}\right) ; \mathrm{T}=25 \pm 1^{\circ} \mathrm{C}$; growing and photosynthesis (duration) -14 days.

${ }^{3}$ stress conditions 3 -Zarrouk's medium that does not contain nitrogen and phosphorus; cultivation in open ponds of the volume $\mathrm{V}=20.0$ l, including the air barbotage (containing $2 \% \mathrm{CO}_{2}$ ); steady-lighting conditions $\mathrm{I}=(215 \pm 5), \mu \mathrm{E} /\left(\mathrm{m}^{2} \mathrm{~s}\right) ; \mathrm{T}=25 \pm 1^{\circ} \mathrm{C}$; growing and photosynthesis (duration) -15 days.

${ }^{4}$ stress conditions $4-1 / 2$ Zarrouk's medium; cultivation in closed bioreactors of the volume $\mathrm{V}=1.01$ including the air barbotage (containing $\left.2 \% \mathrm{CO}_{2}\right)$ tank in the reactor; lighting $\mathrm{I}=(55 \pm 5), \mu \mathrm{E} /\left(\mathrm{m}^{2} \mathrm{~s}\right)$; lighting requirements: light cycles (night/day) $=16: 8 ; \mathrm{T}=21 \pm 1^{\circ} \mathrm{C}$; growing and photosynthesis (duration) - 10 days.

${ }^{5}$ stress conditions 5 - Zarrouk's medium that does not contain nitrogen and phosphorus; cultivation in open ponds of the volume $\mathrm{V}=1.0 \mathrm{l}$; steady-lighting conditions $\mathrm{I}=(400 \pm 5), \mu \mathrm{E} /\left(\mathrm{m}^{2} \mathrm{~s}\right) ; \mathrm{T}=21 \pm 1^{\circ} \mathrm{C}$, growing and photosynthesis (duration) -2 days.

${ }^{6}$ stress conditions 6 - Optimal Haematococcus Medium (OHM) [8] that does not contain nitrogen and phosphorus; cultivation in open ponds of the volume $\mathrm{V}=1.0 \mathrm{l}$; steady-lighting conditions $\mathrm{I}=(450 \pm 50)$, $\mu \mathrm{E} /\left(\mathrm{m}^{2} \mathrm{~s}\right) ; \mathrm{T}=25 \pm 1^{\circ} \mathrm{C}$; growing and photosynthesis (duration) -1 day.
\end{abstract}

\title{
3 Discussion
}

As indicated above, the profitability of fuel production from biomass is determined by competitive prices for hydrocarbon resources. Therefore, at low prices for oil, coal, natural gas, it is economically justified the use of microalgae to produce an expensive by-products (Table 1), and converting of waste to biofuels (e.g., HTL method).

It is shown that as a result of the selection of methods for the microalgae cultivation the biomass with the desired properties can be produced. Thus, the biochemical composition of A. platensis and other MACs showed in the experiments a high lability in relation to environmental conditions. If biomass A. platensis st. rsemsu 1/02-P and st. rsemsu 1/T-02 under standard conditions contained a large amount of protein $(60.7 \pm 2.5 \%$ and $65.6 \pm 2.7 \%)$, and lipid and carbohydrate contents are low (12-13\% and 7-5\%, respectively), in the stress conditions the biochemical composition of both strains becomes more balanced (content of proteins is reduced to $39-24 \%$; content of neutral lipids is increased to $36-47 \%$, and the carbohydrate content - up to 20-34\%). H. pluvialis in response to stress (within 1 day of exposure) reached a significant increase in lipid content (4.2 times), which testifies to its considerable potential. Biosynthesis of the expensive antioxidant - astaxanthin - in the biomass of algae significantly increases the profitability of biofuel production [9].

Thus, the potential biomass of the MAC after the stress may be universal, suitable for producing biodiesel by transesterification of lipids and biodiesel by HTL technology, and to produce biohydrogen, bioethanol and biobutanol. However, first of all, to improve the economic attractiveness of using microalgae it is important to extract from the biomass the most valuable components - phycocyanin, $\beta$-carotene, chlorophyll, B12 (spirulina), astaxanthin, $\beta$-carotene (haematococcus). In case of spirulina rich in protein biomass should be used as a nutraceuticals (BAA).

As noted above, the bio-oil derived from algae has high nitrogen content. Increasing lipid content in cells by means stress and preliminary extraction of proteinaceous compounds may provide substantial reduction of nitrogen content in bio-oil.

For Russia, the production of biofuels from algae is important in connection with the need to achieve a European standard fuel, i.e., for production of gasoline additives. Our experience in large-scale microalgae cultivation provides the basis of organizing industrial production in the Russian Federation $[3,10]$. In connection with the above conditions of microalgae cultivation the task of evaluating territories in terms of their suitability for large-scale microalgae production can be formulated. The list of the most important climatic factors includes the following: 
- Illumination of $4.0 \mathrm{kWh} / \mathrm{m}^{2} /$ day considered sufficient for the microalgae production;

- Preferred ratio of light and dark phases during growth shall be not less than 6:18, as days with less than 6 hours of sunshine are considered to be insufficient for algae growth;

- Cultivation temperature $12^{\circ} \mathrm{C}$. As shown by numerous experiments, spirulina/arthrospira stops growth at temperatures below $12^{\circ} \mathrm{C}$. Various types of microalgae grow over a wide temperature range, but usually, they are sensitive for freezing and therefore cannot survive lowering of the temperature below $0^{\circ} \mathrm{C}$.

For mapping of these factors we used regular spatial grid data from the database NASA Surface meteorology and Solar Energy. Comprehensive analysis of the spatial distribution of the above climatic factors allowed us to identify territories at the South of Russia for more detailed study, which include the Southern, North Caucasian and Crimean Federal Districts, where the climatic conditions are optimal for the cultivation of MACs (Figure 1). The following infrastructural factors were identified for mapping on regional and local scale: 1) availability of water, 2) $\mathrm{CO}_{2}$ sources, 3) low-temperature waters, 4) the available lands for commercial microalgae cultivation (Figure 2).

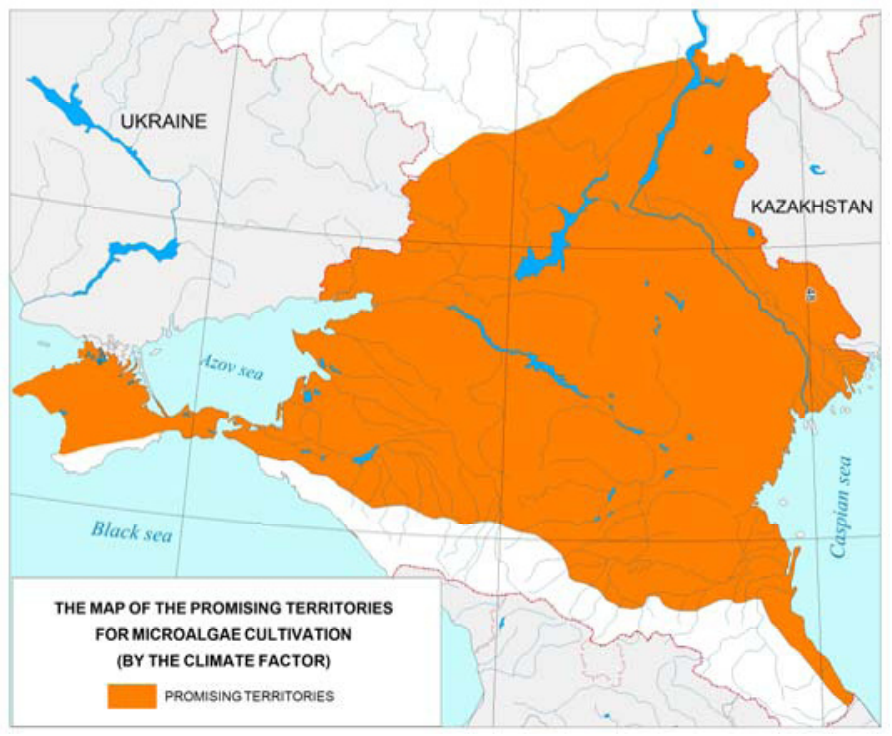

Fig. 1. The map of the promising territories.

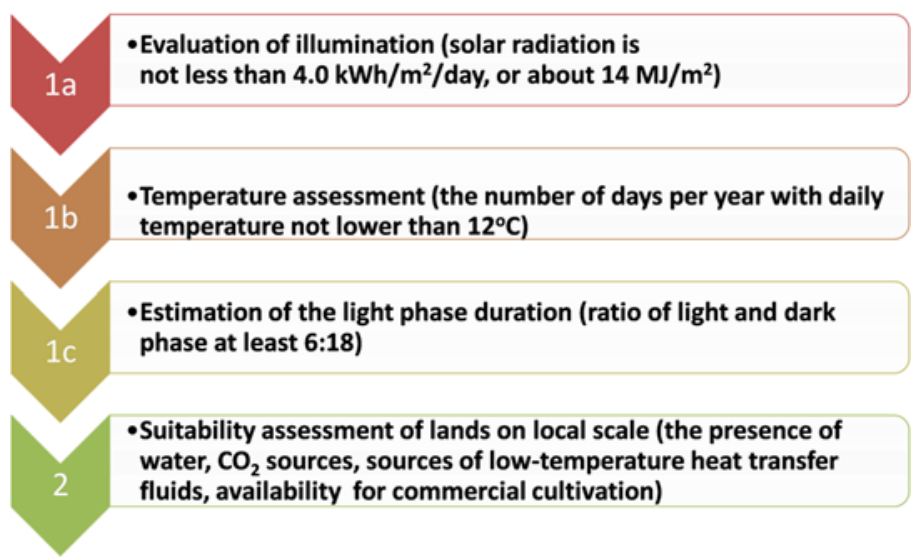

Fig. 2. The sequence of the territory assessment for the large-scale microalgae production by the climatic (1a, 1b, 1c) and infrastructural factors (2). 


\section{Conclusions}

The experimental results of the stressful conditions impact on microalgae strains prove the ability of direct target products obtaining. This allows us to expand the range of biomass processing technologies with appropriate ones for MACs use (transesterification-acetonebutanol-ethanol fermentation-HTL) and a list of relevant energy and by-products (biodiesel, biohydrogen, bioethanol, biobutanol, bio-oil, phycocyanin, beta-carotene, astaxanthin, chlorophyll, B12, feed, food additive). Thus, the sensibility of the biomass to the effects of environmental factors enhances the opportunity for cost-effective microalgae use.

On the basis of own long-term experimental data and literature we stated the list and ranges of climatic and infrastructural factors for selecting suitable territories for large scale microalgae production. Analysis of the spatial distribution for the climatic factors allowed to identify territories of Russia, where the cultivation of MACs could be effective.

This research has been supported by Russian Science Foundation (project № 17-19-01617). The analysis of optimal processing technology applied to investigated strains microalgae was carried out by Vlaskin M.S. and Kiseleva S.V. in Joint Institute for High Temperatures of the Russian Academy of Sciences.

\section{References}

1. L. Rodolfi, G. Chini Zittelli, N. Bassi, G. Padovani, N. Biondi, G. Bonini, M. R. Tredici. Biotechnol. bioeng. 102, 100-112 (2009)

2. L. Raslavičius, V. Semenov, N. Chernova, A. Kersys, A. Kopeyka. Renew. Sust. Energ. Rev. 40, pp. 133-142 (2014)

3. N. Chernova, T. Korobkova, S. Kiseleva. Therm. Eng. 57, 937-945 (2010)

4. N. Chernova, T. Korobkova, S. Kiseleva, S. Zaytsev, N. Radomskii. Sust. Man. Selig. G. (Springer-Verlag, Berlin, 2012)

5. N. Chernova, S. Kiseleva, S. Zajcev. Altern. Energ. Ecol. 12, 70-83 (2014)

6. D. Barreiro, W. Prins, F. Ronsse, W. Brilman. Biom. and Bioen. 53, 113-127 (2013)

7. Katalog cultur microvodoroslei v collektsiyakh SSSR (in Russian) (IPPRAS Publ., Moscow, 1991)

8. J. Fábregas, D. Domínguez, M. Regueiro. Appl. Microbiol. Biotechnol. 53, 530-535 (2000)

9. M. Huntley, D. Redalje. Mitig. Adapt. Strateg. Glob. Chang. 12, 573-608 (2007)

10. N. Chernova, S. Kiseleva., O. Popel'. Therm. Eng. 61, 6 (2014) 